\title{
Diagnosis of bacteremia in pediatric oncologic patients by in-house real-time PCR
}

\author{
Milene Gonçalves Quiles ${ }^{1 *}$, Liana Carballo Menezes ${ }^{1}$, Karen de Castro Bauab ${ }^{1}$, Elke Kreuscher Gumpl ${ }^{1}$, \\ Talita Trevizani Rocchetti ${ }^{1}$, Flavia Silva Palomo ${ }^{1}$, Fabianne Carlesse ${ }^{2}$ and Antonio Carlos Campos Pignatari ${ }^{1}$
}

\begin{abstract}
Background: Infections are the major cause of morbidity and mortality in children with cancer. Gaining a favorable prognosis for these patients depends on selecting the appropriate therapy, which in turn depends on rapid and accurate microbiological diagnosis. This study employed real-time PCR ( $q P C R$ ) to identify the main pathogens causing bloodstream infection (BSI) in patients treated at the Pediatric Oncology Institute IOP-GRAACC-UNIFESP-Brazil. Antimicrobial resistance genes were also investigated using this methodology.

Methods: A total of 248 samples from BACTEC ${ }^{\circledR}$ blood culture bottles and 99 whole-blood samples collected in tubes containing EDTA K2 Gel were isolated from 137 patients. All samples were screened by specific Gram probes for multiplex qPCR. Seventeen sequences were evaluated using gender-specific TaqMan probes and the resistance genes bla $a_{\mathrm{SHV}}$, bla $a_{\mathrm{TEM}}$, bla $a_{\mathrm{CT} X}$, bla $a_{\mathrm{KPC}}$, bla $a_{\mathrm{IMP}}$, bla $a_{\mathrm{SPM}}$, bla $a_{\mathrm{VIM}}$, vanA, vanB and mecA were detected using the SYBR Green method.

Results: Positive qPCR results were obtained in 112 of the blood culture bottles (112/124), and $90 \%$ agreement was observed between phenotypic and molecular microbial detection methods. For bacterial and fungal identification, the performance test showed: sensitivity $87 \%$; specificity $91 \%$; NPV $90 \%$; PPV $89 \%$ and accuracy of $89 \%$ when compared with the phenotypic method. The mecA gene was detected in 37 samples, extended-spectrum $\beta$-lactamases were detected in six samples and metallo- $\beta$-lactamase coding genes in four samples, with $60 \%$ concordance between the two methods. The qPCR on whole blood detected eight samples possessing the mecA gene and one sample harboring the vanB gene. The bla $a_{\mathrm{KPC}}, b / a_{\mathrm{VIM}}, b / a_{\mathrm{IMP}}$ and bla $a_{\mathrm{SHV}}$ genes were not detected in this study.

Conclusion: Real-time PCR is a useful tool in the early identification of pathogens and antimicrobial resistance genes from bloodstream infections of pediatric oncologic patients.
\end{abstract}

Keywords: Real time PCR, Resistance genes, Bloodstream infections, Bacterial pathogens

\section{Background}

In recent decades, the successful treatment of malignancies in children and adolescents has been increasing, with up to $70-80 \%$ of cases having a favorable outcome. However, immunosuppression resulting from treatment makes these patients more susceptible to infections, which are the leading cause of death in this population $[1,2]$.

In these patients, bacteremia often results from infection with one or more microorganisms, predominantly members of the Enterobacteriaceae, Pseudomonas aeruginosa, Streptococcus and Staphylococcus [3, 4]. In a Brazilian

\footnotetext{
* Correspondence: milenequiles@yahoo.com.br

'Special Laboratory of Clinical Microbiology (LEMC), Federal University of São Paulo/UNIFESP, São Paulo, Brazil

Full list of author information is available at the end of the article
}

study of 46 patients who had undergone chemotherapy, 26 were neutropenic and $53 \%$ had positive blood cultures (BC) [1]. Another similar study obtained positive BCs from 41 hospitalized children among a total of 110 patients tested [4]. In Italy, an analysis at 18 centers of 176 episodes of infection found that 123 (64\%) of these cases occurred in neutropenic children versus 68 (36\%) in non-neutropenic children [5].

Bacterial isolation using conventional microbiological techniques rarely exceeds $25 \%$ in children with clinical signs and laboratory findings suggestive of invasive bacterial infection [6, 7]. It is also worth noting that in $40 \%$ of children that have a clinical diagnosis of sepsis and $75 \%$ of high-risk febrile neutropenia cases, the microorganism

Ciomed Central

(c) 2015 Quiles et al. This is an Open Access article distributed under the terms of the Creative Commons Attribution License (http://creativecommons.org/licenses/by/4.0), which permits unrestricted use, distribution, and reproduction in any medium, provided the original work is properly credited. The Creative Commons Public Domain Dedication waiver (http:// creativecommons.org/publicdomain/zero/1.0/) applies to the data made available in this article, unless otherwise stated. 
cannot be detected by currently available conventional microbiological techniques [8].

In this context, the aim of this study was to evaluate the performance of in-house real time PCR (qPCR), applied directly to BACTEC ${ }^{\circledR}$ bottles and whole blood samples, for the detection of 17 relevant microorganisms and 10 antimicrobial resistance genes causing bacteremia in children with cancer. Our hypothesis was that this molecular method could be an accurate and sensitive method for early bacteremia diagnosis in this population.

\section{Methods}

\section{Patients}

We designed a prospective study that was conducted between October 2010 and June 2012 and involved 137 patients admitted to the Institute of Pediatric Oncology (IOP-GRAACC, Brazil), which supports children and adolescents with cancer. Informed consent was obtained from patients, and the study was approved by the Clinical Research Ethics Committee of the hospital.

\section{Blood collection and phenotypic bacterial identification}

Blood samples were collected as part of the standard patient care procedures. The criteria for collecting blood cultures included: fever, defined as a temperature above $38{ }^{\circ} \mathrm{C}$ or above $37.5{ }^{\circ} \mathrm{C}$ for three consecutive measurements, or suggestive clinical signs of sepsis.

At the onset of fever or in the presence of clinical symptoms, two sets of BCs were taken from peripheral venous access or from the central line catheter. Bloodstream infection (BSI) was defined as the isolation of a bacterial or fungal pathogen from at least one BC [9]. All episodes of BSI were then sub-classified as a singleagent (Gram-positive, Gram-negative or fungi) or polymicrobial. For polymicrobial BSI, two or more pathogens were isolated from a single $\mathrm{BC}$ or at least two separate $\mathrm{BCs}, 96 \mathrm{~h}$ apart. BCs were performed using the BACTEC $^{\circledR} 9240$ instrument (Becton Dickinson, Microbiology Systems, Cockeysville, MD, USA). BC bottles were designated positive after detection of bacterial growth. Samples were negative when no bacterial growth was detected after five days incubation. Identification at the species level and susceptibility testing were performed using the automated system Phoenix 100 (Becton Dickinson, Microbiology Systems).

Whole blood samples were collected at the same time and following the same criteria when possible. These samples were not analyzed phenotypically but instead were subjected to molecular assays.

\section{Molecular detection of microorganisms and resistance genes}

Chromosomal DNA was extracted from $500 \mu$ of positive and negative $\mathrm{BC}$ samples after incubation on BACTEC $^{\circledR}$
9240, using the phenol-chloroform method (Brazol; LGC Biotechnologia, Cotia, Brazil) with $300 \mathrm{mg}$ glass beads $(0.3 \mathrm{~mm}$ diameter; Scientific Industries, Bohemia, NY, USA), and were processed in a disruptor Genie (Scientific Industries) for $10 \mathrm{~min}$ to achieve cell lysis. In parallel, chromosomal DNA was extracted from $1.5 \mathrm{ml}$ of whole blood samples using the QIAamp DNA blood kit (Qiagen Inc., Valencia, CA, USA). Extracted DNA was diluted (1:10) using DNase/RNase-free distilled water UltraPure (Invitrogen, Carlsbad, CA, USA) for reducing the inhibitor reagents in the sample. Extracted DNA was used for the detection of pathogens and resistance genes by our inhouse qPCR assay.

The primers used for detection of the resistance genes bla $a_{\mathrm{SHV}}, b l a_{\mathrm{TEM}}, b l a_{\mathrm{CTX}-\mathrm{M}}, b l a_{\mathrm{IMP}}, b l a_{\mathrm{SPM}}, b l a_{\mathrm{VIM}}, b l a_{\mathrm{KPC}}$, van $\mathrm{A}, \operatorname{van} \mathrm{B}$ and $m e c \mathrm{~A}$, have been described previously $[8,10-12]$, as have the primers and TaqMan probes for multiplex qPCR detection of Gram-positive (GP) and Gram-negative (GN) bacteria and specific-species detection of Enterococcus spp., coagulase negative Staphylococcus (CoNS), S. aureus, Streptococcus pneumoniae, Escherichia coli, Klebsiella pneumoniae, Enterobacter cloacae, Proteus mirabilis, Salmonella spp., Serratia marcescens, Acinetobacter baumannii, Pseudomonas aeruginosa, Stenotrophomonas maltophilia, Mycobacterium tuberculosis, Aspergillus spp., Candida spp. and Fusarium spp. [13, 14]. A primer set for the hemochromatosis gene (HFE) was designed to be used as an internal control of DNA extraction. The analytical validations of these tests have been described previously [14].

The presence of bacterial DNA in the sample was first screened by a TaqMan-based multiplex qPCR using universal primers for the $16 \mathrm{~S}$ rDNA gene for differentiation between Gram-positive and Gram-negative bacteria. Species identification was performed by a Taqman-based monoplex qPCR. Amplification for the TaqMan probe reaction was performed in a $20 \mu \mathrm{l}$ reaction volume, using $10 \mu \mathrm{l}$ TaqMan Universal Master Mix 2× (Applied Biosystems), $5 \mu$ l template DNA, $0.5 \mu \mathrm{M}$ each primer and $0.3 \mu \mathrm{M}$ probe. The qPCR conditions were as follows: $50{ }^{\circ} \mathrm{C}$ for 2 min and $95{ }^{\circ} \mathrm{C}$ for $10 \mathrm{~min} ; 40$ cycles of $95{ }^{\circ} \mathrm{C}$ for $15 \mathrm{~s}$ and $60{ }^{\circ} \mathrm{C}$ for $60 \mathrm{~s}$.

Resistance gene amplification by SYBR Green monoplex qPCR was performed in a $25 \mu$ reaction mixture containing $12.5 \mu$ l Platinum SYBR Green qPCR SuperMix (Invitrogen, Carlsbad, CA, USA), $0.5 \mu \mathrm{M}$ each primer, and $5 \mu \mathrm{l}$ of DNA extracted from samples. The qPCR conditions were as follows: $50{ }^{\circ} \mathrm{C}$ for $2 \mathrm{~min}$ and $95{ }^{\circ} \mathrm{C}$ for $10 \mathrm{~min} ; 40$ cycles of $95{ }^{\circ} \mathrm{C}$ for $15 \mathrm{~s}$ and $60{ }^{\circ} \mathrm{C}$ for $60 \mathrm{~s}$; and a melting curve step (from $68{ }^{\circ} \mathrm{C}$ to $95{ }^{\circ} \mathrm{C}$ in increments of $\left.0.5{ }^{\circ} \mathrm{C} / \mathrm{s}\right)$. Metallo- $\beta$-lactamase $(\mathrm{M} \beta \mathrm{L})$ detection was performed by multiplex qPCR [13]. The ABI 7500 real-time PCR System (Applied Biosystems) instrument was quantified online and at the endpoint 
with the sequence detection system software (version 2.0; Applied Biosystems).

The number of DNA molecules present in the sample was determined based on the amount of fluorescence detected by the qPCR instrument. This quantified fluorescence resulted in a Cycle Threshold value $(\mathrm{Ct})$ that corresponds to the number of amplification cycles required to obtain a given amount of DNA [15].

\section{Additional tests to confirm the susceptibility profile}

Samples with discordant susceptibility profiles between molecular and phenotypic analyses were subjected to further testing to confirm the results. For GN samples with discordant $\mathrm{M} \beta \mathrm{L}$ or extended-spectrum $\beta$-lactamase $(\mathrm{ES} \beta \mathrm{L})$ profiles, we conducted a $\mathrm{qPCR}$ assay directly from the clinical strain recovered from our collection of microorganisms. These strains were stored at $-20{ }^{\circ} \mathrm{C}$ in tryptone soya broth containing glycerol and were subcultured on blood agar for isolation. DNA extraction and qPCR were performed following the protocols described above.

For methicillin-resistant Staphylococcus strains with discordant profiles, we performed the qPCR directly from the clinical strain and confirmed the minimum inhibitory concentration (MIC) for oxacillin with an Etest ${ }^{\circledR}$. The diameter of the zone for cefoxitin was determined by the disc diffusion test following the Clinical \& Laboratory Standards Institute recommendations [16].

\section{Statistical analysis}

Data collection and statistical analysis were performed using SPSS version 17.0 software (SPSS Inc., Chicago, IL, USA) and Microsoft Office Excel 2010 (Microsoft, Redmond, WA, USA). Comparison of the BC identification by phenotypic methods versus qPCR results was evaluated by $\chi 2$ tests. Discordance between the results from the two methods was assessed using McNemar's test (statistical significance was set at a two-tailed exact test, based on a binomial distribution with $p=\mathrm{q}=0.5$ ). The $K$ statistic was calculated to measure the level of agreement between phenotypic and qPCR results directly from $\mathrm{BC}$ bottles.

\section{Results}

A total of 347 samples from 137 patients admitted to the IOP/GRAACC were included in this study. These samples included $248 \mathrm{BC}$ bottles and 99 whole blood samples collected in EDTA tubes. Clinical data from patients were collected by the Center of Infection Control at the Institute. Among these 248 BC bottles, $53.2 \%$ ( $n=132)$ were obtained from peripheral venous access and $46.8 \%(n=116)$ from the central line catheter.

The average age of patients was nine years old (ranging from 0 to 25$) ; 64$ (46\%) were female and 74 (54\%) were male. Underlying diseases were blastoma (19\%), acute lymphoblastic leukemia (15\%), general tumors (15\%), sarcoma (13\%) and non-Hodgkin lymphoma (12\%). Among 137 patients, 17 were submitted for allogeneic bone marrow transplant, 15 for autologous bone marrow transplant and one for liver transplantation. Sulfamethoxazole and trimethoprim antibiotic prophylaxis was used in patients with leukemia, lymphoma and in those with a solid tumor who received corticosteroids above $2 \mathrm{mg} / \mathrm{kg}$.

\section{Phenotypic testing}

Initial phenotypic analyses from 248 BCs identified 127 (51.2 \%) negative and 121 (48.8\%) positive samples. Three episodes were classified as polymicrobial with two agents detected in one sample. Thus, a total of 124 strains were identified by this method: 67 (54.0\%) GP, $43(34.7 \%)$ GN species. The main pathogens identified were CoNS $(n=35)$ and $P$. aeruginosa $(n=14)$ (Table 1$)$. Fungi species were detected in 14 (11.3\%) samples and the main agent identified was Candida spp. $(n=12)$.

The susceptibility testing performed on positive samples detected 31 (88 \%) methicillin-resistant CoNS, 8 (66\%) methicillin-resistant $S$. aureus and two vancomycinresistant E. faecium. Nine ES $\beta$ L Enterobacteriaceae producers and 12 carbapenem-resistant $P$. aeruginosa strains were detected among the GN strains.

\section{Molecular testing from $\mathrm{BC}$ bottles}

All samples included in the study were positive for the HFE gene, which indicated that the DNA had been successfully extracted. qPCR for GP/GN $16 \mathrm{~S}$ rDNA from the 248 BCs samples detected $112(90.3 \%)$ positive samples versus the 124 detected by $\mathrm{BC}$ processing. Among 69 GP and 42 GN strains identified by BC, the qPCR method was able to identify 58 (86.5\%) GP and 40 (95.2 \%) GN samples (Table 1). The overall concordance between the phenotypic and molecular methods was $89 \%$ for GP and $90 \%$ for GN detection with a Cohen $\mathrm{k}$ coefficient of 0.775 (p-value $<0.001$ and $95 \%$ CI: 0.651-0.899).

Since the qPCR assay applied in this study was standardized to detect 17 different species from clinical samples, 24 samples containing different species were not identified. The species identified were 15 non-fermenter bacteria, 18 Enterobacteriaceae, 32 CoNS, $10 \mathrm{~S}$. aureus, one Streptococci and five Enterococci (Table 1). There was a discrepancy for one sample that was identified as $S$. aureus by the phenotypic method and as CoNS by qPCR. The molecular method did not identify four GP samples. One false-positive sample was detected by qPCR with a 12,703 Ct rate, and this was identified as CoNS. Candida species were identified in 3 (25\%) samples. 
Table 1 Comparison of phenotypic and molecular assays apllied to bloodculture bottles

\begin{tabular}{|c|c|c|c|c|c|c|}
\hline & $\begin{array}{l}\text { Phenotipyc detection and } \\
\text { identification by phenotypic } \\
\text { analisys ( } n=124)\end{array}$ & $\begin{array}{l}\text { Molecucar detection } \\
\text { by GP/GN } \\
\text { multiplex PCR }\end{array}$ & Concordance (\%) & $\begin{array}{l}\text { Molecular identification } \\
\text { by specific-species qPCR } \\
(n=124)\end{array}$ & Concordance (\%) & $\begin{array}{l}\text { Average Cycle } \\
\text { threshold }\end{array}$ \\
\hline S. aureus & 12 & 12 & $100 \%$ & 10 & $83.40 \%$ & 17,683 \\
\hline SCON & 35 & 28 & $80 \%$ & 32 & $91.40 \%$ & 20,608 \\
\hline $\begin{array}{l}\text { Enterococcus } \\
\text { spp. }\end{array}$ & 5 & 5 & $100 \%$ & 5 & $100 \%$ & 24,923 \\
\hline S. pneumoniae & 1 & 1 & $100 \%$ & 1 & $100 \%$ & 20,977 \\
\hline K. pneumoniae & 3 & 3 & $100 \%$ & 3 & $100 \%$ & 29,111 \\
\hline E. cloacae & 6 & 6 & $100 \%$ & 6 & $100 \%$ & 20,919 \\
\hline E. coli & 8 & 7 & $87.50 \%$ & 7 & $87.50 \%$ & 18,995 \\
\hline S. marcescens & 2 & 2 & $100 \%$ & 2 & $100 \%$ & 25,252 \\
\hline P. aeruginosa & 14 & 13 & $92.80 \%$ & 13 & $92.80 \%$ & 19,395 \\
\hline S. malthofilia & 1 & 1 & $100 \%$ & 1 & $100 \%$ & 36,974 \\
\hline $\begin{array}{l}\text { Acinetobacter } \\
\text { spp. }\end{array}$ & 1 & 1 & $100 \%$ & 1 & $100 \%$ & 27,993 \\
\hline Candida spp. & 12 & 12 & $100 \%$ & 3 & $25 \%$ & 25,464 \\
\hline Other fungi & 2 & 2 & $100 \%$ & a & a & a \\
\hline $\begin{array}{l}\text { Streptococcus } \\
\text { sp. }\end{array}$ & 9 & 7 & $77.80 \%$ & a & a & a \\
\hline Others & 13 & 12 & $92.30 \%$ & a & a & a \\
\hline
\end{tabular}

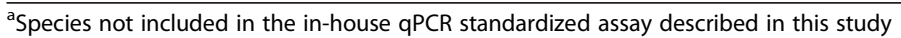

For real-time PCR directly from BC bottles the performance test showed: sensitivity $90 \%$; specificity $88 \%$; negative predictive value (NPV) $88 \%$; positive predictive value (PPV) $90 \%$ and accuracy of $89 \%$ for GP and GN detection when compared with the phenotypic method from BC bottles. For bacterial and fungal identification the performance test showed: sensitivity $87 \%$; specificity $91 \%$; NPV 90 \%; PPV $89 \%$ and accuracy of $89 \%$ when compared with the phenotypic method.

The qPCR for resistance genes detected four Enterobacteriaceae strains possessing the $b l a_{\mathrm{CTX}}$ gene. Three of these samples were positive for the phenotypic detection of ES $\beta \mathrm{L}$ while one sample was ES $\beta \mathrm{L}$ negative and cephalosporin susceptible as determined by phenotypic analysis. In one ES $\beta \mathrm{L}$-producer $K$. pneumoniae strain, the qPCR detected both $b l a_{\mathrm{TEM}}$ and $b l a_{\mathrm{CTX}}$ genes. One ES $\beta L$ E. coli strain was identified that contained the blaTEM gene. Four carbapenem-resistant $P$. aeruginosa were positive for the $b l a_{\mathrm{SPM}}$ gene. Other GN resistant genes were not detected. The molecular method was not able to detect any resistance genes from eight carbapenemresistant $P$. aeruginosa strains and six samples with an ES $\beta \mathrm{L}$ profile. The concordance between molecular and phenotypic analysis of the susceptibility profile was $60 \%$.

Among GP strains, 37 methicillin-resistant samples were detected that possessed the mecA gene (30 CoNS and seven $S$. aureus). There was a discrepancy for three samples. The concordance between both methods was $92.5 \%$. Two vancomycin-resistant Enterococci were positive for the vanA gene with $100 \%$ concordance.

Eight carbapenem-resistant $P$. aeruginosa isolates that tested negative for resistance genes on qPCR were subjected to qPCR directly from the clinical strain. Three of these samples were positive for $b l a_{\mathrm{SPM}}$ in the second test. The other five isolates remained negative for resistance genes. One E. coli $\mathrm{BC}$ sample that tested positive for the $b l a_{\text {СтX }}$ gene and showed susceptibility to all cefalosporins was negative for this gene when tested directly from the isolate.

Three discordant Staphylococcus samples were subjected to confirmatory tests. Two methicillin-resistant strains (one CoNS and one $S$. aureus) that were negative for the mecA gene when tested from $\mathrm{BC}$ bottles, tested $m e c \mathrm{~A}$ positive in the $\mathrm{qPCR}$ directly from the isolated strain. One $S$. aureus sample considered phenotypically susceptible to methicillin tested positive for mecA both from $\mathrm{BC}$ bottles and the isolated strain. All three samples showed a high MIC for this drug and were resistant in the disc diffusion test.

\section{Molecular analysis of whole blood samples}

A total of 99 whole blood samples were analyzed in this study. A positive result was obtained for the $16 \mathrm{~S}$ rDNA qPCR in $12(12.1 \%)$ samples, of which two were 
amplified for both GP and GN and 10 only for GP (Table 2). The concordance between the phenotypic analysis of paired BCs of these samples and whole blood was $67.7 \%$.

The qPCR for specific species identified CoNS $(n=25)$, S. aureus $(n=2)$, Enterococcus spp. $(n=2)$, S. pneumoniae $(n=1)$, E. coli $(n=1), P$. aeruginosa $(n=1)$ and Candida spp. ( $n=1)$ with $55 \%$ concordance with phenotypic identification from paired BCs. One sample showed a discrepancy with phenotypic detection of E. cloacae and qPCR detection of $S$. aureus and CoNS. We identified 14 false-positive samples from qPCR, one Candida spp. and 13 CoNS. This technique was not able to detect eight positive samples $(8.1 \%)$.

The mecA gene was identified from 11 samples of which three were methicillin-resistant on BC with $60 \%$ concordance. The van A gene was detected in one vancomycin-resistant sample. Other resistance genes were not detected from whole blood samples. The degree of concordance between the phenotypic susceptibility test from paired $\mathrm{BCs}$ and $\mathrm{qPCR}$ from whole blood was $59 \%$.
The overall concordance between the qPCR from BC bottles and whole blood samples was $82 \%$ with a Cohen $\mathrm{K}$ coefficient of 0.702 ( $p$-value $<0.001$ and $95 \% \mathrm{CI}$ : 0.502 e 0.903$)$.

\section{Discussion}

Patients with cancer, especially children, are susceptible to various infections because of immunosuppression caused by the treatment. These infections are difficult to treat and the agent is only identified in $22-39 \%$ of cases [17]. Effective identification of the causative agent and the correct choice of antimicrobial therapy is crucial for reducing mortality in these patients [7].

When conventional techniques are used to identify bacteria and fungi, only up to $25 \%$ of the episodes of bacteremia are detected in children with clinical and laboratory findings. In approximately $40 \%$ of children diagnosed with sepsis and $75 \%$ with neutropenia, the microorganism is not detected. Several studies have suggested that applying molecular methods directly to clinical samples could be a rapid and accurate tool for diagnosis in these patients [7]. In this study, we compared phenotypic

Table 2 Phenotypic and molecular results from whole blood samples and paired BC bottles

\begin{tabular}{|c|c|c|c|c|c|}
\hline BC Sample (BACTEC) & $\begin{array}{l}\text { Whole blood } \\
\text { sample (EDTA) }\end{array}$ & $\begin{array}{l}\text { Specie isolated from } \\
\mathrm{BC} \text { bottle }\left(\text { Phoenix }{ }^{\circledR} \text { ) }\right.\end{array}$ & $\begin{array}{l}\text { Susceptibility } \\
\text { profile }\left(\text { Phoenix }{ }^{\circledR}\right)\end{array}$ & $\begin{array}{l}\mathrm{qPCR} \text { from BC bottles } \\
\text { for resistance genes (ct) }\end{array}$ & $\begin{array}{l}\text { QPCR from whole blood } \\
\text { for resistance genes (ct) }\end{array}$ \\
\hline 195 & 176 & S. aureus & Oxacillin S & mecA $(21,855)$ & $\operatorname{mec} A(33,021)$ \\
\hline 178 & 117 & a & a & ND & mecA $(34,520)$ \\
\hline 190 & 152 & E. coli & Carbapenem S & ND & ND \\
\hline 191 & 174 & P. aeruginosa & Carbapenem S & ND & ND \\
\hline 283 & 133 & E. cloacae & Carbapenem S & ND & ND \\
\hline 391 & 255 & P. putida & Carbapenem S & ND & ND \\
\hline 404 & 232 & Enterococcus sp & Vancomicyn S & ND & ND \\
\hline 341 & 233 & S. aureus & Oxacillin $\mathrm{R}$ & mecA $(28,550)$ & mecA $(31,653)$ \\
\hline 371 & 240 & B. cepacia & Carbapenem S & ND & ND \\
\hline 400 & 252 & B. cepacia & Carbapenem S & ND & ND \\
\hline 477 & 288 & S. epidermidis & Oxacillin R & mecA $(23,914)$ & $\operatorname{mec} A(33,211)$ \\
\hline 389 & 237 & E. coli & Carbapenem S & ND & ND \\
\hline 369 & 244 & SCON & Oxacillin S & ND & mecA $(33,073)$ \\
\hline 372 & 247 & P. aeruginosa & Carbapenem S & ND & ND \\
\hline 373 & 254 & S. epidermidis & Oxacillin R & $\operatorname{mec} A(15,683)$ & mecA $(29,909)$ \\
\hline 392 & 241 & S. haemolyticus & Oxacillin $\mathrm{R}$ & $\operatorname{mec} A(20,648)$ & $\operatorname{mec} A(37,468)$ \\
\hline 431 & 276 & SCON & Oxacillin R & mecA $(15,902)$ & $\operatorname{mec} A(37,320)$ \\
\hline 465 & 293 & P. aeruginosa & Carbapenem R & ND & ND \\
\hline 441 & 273 & S. epidermidis & Oxacillin R & ND & ND \\
\hline 422 & 264 & S. aureus & Oxacillin R & $\operatorname{mec} A(16,508)$ & mecA $(35,945)$ \\
\hline 423 & 265 & SCON & Oxacillin R & mecA $(15,513)$ & $\operatorname{mec} A(36,217)$ \\
\hline 470 & 290 & E. faecium & Vancomicyn $\mathrm{R}$ & $\operatorname{vanA}(17,560)$ & $\operatorname{vanA}(24,938)$ \\
\hline
\end{tabular}

$B C$ Bloodculture bottle, ct cycle threshold, $R$ resistant, $S$ Susceptible, ND Not detected

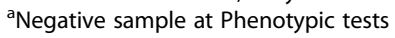


and molecular assays for the detection and identification of microorganisms from clinical samples and performed susceptibility testing.

We observed that the molecular method was not able to detect 13 samples (three GN and nine GP) that were detected by $\mathrm{BC}$ processing and 16 samples were not identified at the species level. Other studies have also reported discordant results when comparing two or more methodologies for bacterial detection and identification from clinical samples [17]. These discrepancies may be caused by the presence of substances such as heme, IgG, sodium polyanethol sufonate or hemocomponents, in clinical samples or BACTEC ${ }^{\circledR}$ bottles $[18,19]$.

One false positive result was identified as GP and CoNS by qPCR assays with a Ct rate of 12,793 . This patient gave a positive $\mathrm{BC}$ result with CoNS two days later, suggesting that the infection was also present in the previous sample but was not detectable by the phenotypic method. Similar results have been reported in other studies in which pathogens detected only by PCR were also present in other samples from the same patient that tested negative on phenotypic testing [20,21].

The results obtained using the qPCR and phenotypic methods for determining methicillin susceptibility showed discrepancies in three $S$. aureus samples. One $S$. aureus sample was detected as methicillin susceptible, but the $m e c \mathrm{~A}$ gene was detected by qPCR. The other two samples were methicillin resistant, but the mecA gene was not detected in BC samples. When qPCR was performed directly from the clinical isolate strains and confirmatory tests for methicillin susceptibility were conducted, these three samples were determined to be methicillin resistant. These findings illustrated the fact that both phenotypic and molecular methods were not $100 \%$ accurate at determining the susceptibility profile of clinical samples. The correlation between detection of methicillin resistance by the phenotypic method and detection of the mecA gene by SeptiFast ${ }^{\circledR}$ was evaluated in a recent study and the molecular method was unable to detect the mecA gene in two samples. The authors suggested that this was due to the difference in sensitivity between the two tests: one was conducted directly from clinical samples and the other directly from the isolates [22].

The phenotypic results of susceptibility tests of GN isolates compared with the qPCR results showed discrepancies in ESBL detection for six samples. In this study we did not evaluate the presence of the enzyme groups VEB, GES, PER, and OXA, which can eventually be found composing the same integron and are sporadically reported in some countries in South America [23-25].

Five carbapenem-resistant samples were detected in this study that were negative for the $\mathrm{M} \beta \mathrm{L}$-coding gene $b l a_{S P M}$, even when analyzing the clinical isolate. A Brazilian study reported a rate of $81.1 \%$ carbapenem-resistant
$P$. aeruginosa strains that were non-M $\beta \mathrm{L}$ producing [26]. Another study conducted at the same institution demonstrated that isolates of $P$. aeruginosa resistant to carbapenems that lacked $\mathrm{M} \beta \mathrm{L}$ production had been detected in their hospital since 2000 , and they proposed that other resistance mechanisms may be involved, such as changes in permeability through the membrane, porin loss or efflux systems [27].

The qPCR assay is not sufficiently comprehensive to detect all of the possible mechanisms of resistance expressed by microorganisms. However, because it is an "in-house" method, it is possible to customize the assay by adding or deleting genes to be tested depending on the particular resistance mechanisms of interest.

Our molecular method was able to detect the presence of fungi DNA in $100 \%$ of samples determined to be positive by the phenotypic method $(n=14)$, however, it was only able to detect the specific species in three samples of Candida spp. It has previously been suggested that some positive samples may not be detected by commercial kits because the concentration of microorganisms in $\mathrm{BC}$ bottles is usually less than $100 \mathrm{CFU} / \mathrm{mL}$ [28].

Molecular analysis of whole blood directly was able to detect $12.1 \%$ of GP/GN positive samples. The qPCR also detected one vancomycin-resistant E. faecium sample containing van A and 11 mecA positive samples, of which six gave the same result using the automated system. A study conducted with 23 episodes of febrile neutropenia in children detected the presence of bacterial DNA in three cases (13\%) by culture and in 11 cases (48 \%) by PCR [29]. In another study conducted in Chile of children with cancer in which molecular detection of three species ( $S$. aureus, $P$. aeruginosa and E. coli) directly from whole blood was performed, the authors reported a positivity rate of $20 \%$ [7].

Some authors have reported higher sensitivity for detecting pathogens directly from whole blood $[7,30]$ and suggest that the volume of blood collected is highly dependent upon the weight of the patient. They concluded that it is necessary to collect up to $4.5 \%$ of blood volume (about $4 \mathrm{ml} / \mathrm{kg}$ ) to detect low concentrations of pathogens in blood [31]. The methodology applied in our study determined a volume of $1.5 \mathrm{ml}$ of whole blood, regardless of patient weight. When considering only children and adolescents (as in our study), taking into account the weight of each patient when determining the volume of the sample to be collected would improve the sensitivity of the method.

\section{Conclusion}

Real-time PCR applied directly to samples from positive bloodstream bottles or whole blood samples constitutes an accurate tool for the early identification of pathogens and antimicrobial resistance genes in bloodstream 
infections of pediatric oncologic patients. In addition to providing clinical data relevant to each individual patient, these molecular results would be invaluable in determining appropriate, patient-specific, antibiotic therapy.

\section{Abbreviations}

PCR: Polymerase chain reaction; qPCR: Real-time polymerase chain reaction; BC: Bloodculture; BSI: Bloodstream infection; GP: Gram-positive; GN: Gram-negative; CoNS: Coagulase negative Staphylococcus; HFE: Hemochromatosis; M $\beta$ L: Metallo- $\beta$-lactamase; Ct: Cycle Threshold value; ES $\beta$ L: Extended-spectrum $\beta$-lactamase; MIC: Minimum inhibitory concentration.

\section{Competing interests}

The authors declare that they have no competing interests.

\section{Authors' contributions}

MGQ carried out the PCR experiments and data analysis, and drafted the manuscript. LCM participated in the design of the study and provided support for molecular analyses. KCB participated in the design of the study and provided support for molecular analyses. EKG helped perform the PCR experiments. TTR participated in the design of the study. FSP participated in sample collection and the phenotypic experiments. FC participated in clinical data acquisition. ACCP participated in the design and coordination of the study. All authors read and approved the final manuscript.

\section{Acknowledgment}

This study was supported by a grant from Fundação de Amparo à Pesquisa do Estado de São Paulo - FAPESP, Brazil.

\section{Author details}

${ }^{1}$ Special Laboratory of Clinical Microbiology (LEMC), Federal University of São Paulo/UNIFESP, São Paulo, Brazil. ${ }^{2}$ Institute of Pediatric Oncology IOP-GRAACC, Federal University of São Paulo, São Paulo, Brazil.

Received: 13 October 2014 Accepted: 16 July 2015

Published online: 23 July 2015

\section{References}

1. Miranda APR, Rocha PR, Júdice OM. Neutropenia febril: experiência do serviço de oncologia pediátrica do serviço de cirurgia pediátrica do hospital universitário da universidade de Brasília. Brasília Med. 2002;39:16-21.

2. Adamsky J, Steggall M, Yeoh XK, Makin GW. Outcome of gram negative infection in immunocompromised children. Pediatr Blood Cancer. 2008:51:499-503.

3. Velasco E, Byington R, Martins ASC, Schirmer M, Dias LC, Gonçalves VM. Bloodstream infection surveillance in a cancer centre: a prospective look at clinica microbiology aspects. Clin Microbiol Infect. 2004;10:542-9.

4. Greenberg D, Moser A, Yagupsky P, Peled N, Hofman Y, Kapelushnik J, et al. Microbiological spectrum and susceptibility patterns of pathogens causing bacteraemia in paediatric febrile neutropenic oncology patients: comparison between two consecutive time periods with use of different antibiotic treatment protocols. Int J Antimicrob Agents. 2005;25(6):469-73.

5. Viscoli C, Bruzzi P, Castagnola E, Boni L, Calandra T, Gaya H, et al. Factors associated with bacteraemia in febrile, granulocytopenic cancer patients. The international antimicrobial therapy cooperative group (IATCG) of the European organization for research and treatment of câncer (EORTC). Eur J Cancer. 1994;30A(4):430-7.

6. Rackoff WR, Gonin R, Robinson C, Kreissman SG, Breitfeld PB. Predicting the risk of bacteremia in children with fever and neutropenia. J Clin Oncol. 1996;14(3):919-24.

7. Santolaya ME, Farfán MJ, De La Maza V, Cociña M, Santelices F, Alvarez AM, et al. Diagnosis of bacteremia in febrile neutropenic episodes in children with cancer: microbiologic and molecular approach. Pediatr Infect Dis J. 2011;30(11):957-61.

8. Dutka-Malen S, Evers S, Courvalin P. Detection of glycopeptide resistance genotypes and identification to the species level of clinically relevant enterococci by PCR. J Clin Microbiol. 1995;33(1):24-7.
9. Garner JS, Jarvis WR, Emori TG. CDC definition for nosocomial infections. Am J Infect Control. 1988;16:128-40.

10. Mendes RE, Kiyota KA, Monteiro J, Castanheira M, Andrade SS, Gales AC, et al. Rapid detection and identification of metallo- $\beta$ - lactamase encoding genes by multiplex real-time PCR assay and melt curve analysis. J Clin Microbiol. 2007:45:544-7.

11. Monstein HJ, Östholm-Balkhed $\AA$, Nilsson VM, Nilsson M, Dornbusch K, Nilsson EL. Multiplex PCR amplification assay for the detection of blaSHV blaTEM and blaCTX-M genes in Enterobacteriaceae. APMIS. 2007;115(12):1400-8.

12. Zhang K, McClure JA, Elsayed S, Louie T, Conly JM. Novel multiplexPCR assay for characterization and concomitant subtyping of staphylococcalcassette chromosome mec types I to $\mathrm{V}$ in methicillin-resistant Staphylococcus aureus. J Clin Microbiol. 2005;43:5026-33.

13. Bispo PJ, Melo GB, Hofling-Lima AL, Pignatari ACC. Detection and gram discrimination of bacterial pathogens from aqueous and vitreous humor using real-time PCR assays. Invest Ophthalmol Vis Sci. 2011;52:873-81.

14. Menezes LC, Rocchetti TT, Bauab KC, Cappellano P, Quiles MG, Carlesse F, et al. Diagnosis by real-time polymerase chain reaction of pathogens and antimicrobial resistance genes in bone marrow transplant patients with bloodstream infections. BMC Infect Dis. 2013. doi:10.1186/1471-2334-13-166.

15. Kubista M, Andrade JM, Bengtsson M, Forootan A, Jonák J, Lind K. The real-time polymerase chain reaction. Mol Aspect Med. 2006;27:95-125.

16. Clinical and Laboratory Standards Institute. Performance standards for antimicrobial susceptibility testing. 23Th Informational Supplement, Clinical and laboratory standards (M100-S23). PA: Wayne; 2014.

17. Gaytán-Martínez J, Casanova-Cardiel J, Mateos-García LJ, Fuentes-Allen E, Sánchez-Cortés E, González-Llaven JL. Microbiological findings in febrile neutropenia. Arch Med Res. 2000;31(4):388-92.

18. Varani S, Stanzani M, Paolucci M, Melchionda F, Castellani G, Nardi L, et al. Diagnosis of bloodstream infectious in immunocompromised patients by real-time PCR. J Infect. 2009;58(5):346-51.

19. Al-Soud WA, Radstrom P. Purification and characterization of PCR-inhibitory components in blood cells. J Clin Microbiol. 2001;39:485-93.

20. Dierkes C, Ehrenstein B, Siebig S, Linde HJ, Reischl U, Salzberger B. Clinical impact of a commercially available multiplex PCR system for rapid detection of pathogens in patients with presumed sepsis. BMC Infect Dis. 2009:9:126

21. Mancini N, Carletti S, Ghidoli N, Cichero P, Burioni R, Clementi M. The Era of molecular and other Non-culture-based methods in diagnosis of sepsis. Clin Microbiol Rev. 2010;23:235-51.

22. Yanagihara K, Kitagawa Y, Tomonaga M, Tsukasaki K, Kohno S, Seki M, et al. Evaluation of pathogen detection from clinical samples by real-time polymerase chain reaction using a sepsis pathogen DNA detection kit. Crit Care. 2010;14(4):159.

23. Celenza G, Pellegrini C, Caccamo M, Segatore B, Amicosante G, Perilli M. Spread of blaCTX-M-type and blaPER-2 beta-lactamase genes in clinical isolates from Bolivian hospitals. J Antimicrob Chemother. 2006:57(5):975-8.

24. Dropa M, Balsalobre LC, Lincopan N, Mamizuka EM, Cassettari VC, Matte GR, et al. Emergence of Klebsiella pneumoniae carrying the novel extendedspectrum beta-lactamase gene variants bla(SHV-40), bla(TEM-116) and the class 1 integron-associated bla(GES-7) in Brazil. Clin Microbiol Infect. 2010;16:630-2.

25. Vignoli R, Varela G, Mota MI, Cordeiro NF, Power P, Ingold E, et al. Enteropathogenic Escherichia coli strains carrying genes encoding the PER-2 and TEM-116 extended-spectrum beta-lactamases isolated from children with diarrhea in Uruguay. J Clin Microbiol. 2005:43:2940-3.

26. Marra AR, Camargo LF, Pignatari AC, Sukiennik T, Behar PR, Medeiros EA, et al. Nosocomial bloodstream infections in Brazilian hospitals: analysis of 2,563 cases from a prospective nationwide surveillance study. J Clin Microbiol. 2011;49(5):1866-71

27. Fernandes TA, Pereira CAP, Petrilli AS, Pignatari ACC. Caracterização molecular de Pseudomonas aeruginosa resistentes à carbapenêmicos e produtores de metalo-B-lactamase isoladas em hemoculturas de crianças e adolescentes com câncer. Rev Soc Bras Med Tropical. 2010;43(4):372-6.

28. von Lilienfeld-Toal M, Lehmann LE, Raadts AD, Hahn-Ast C, Orlopp KS, Marklein G, et al. Utility of a commercially available multiplex real-time PCR assay to detect bacterial and fungal pathogens in febrile neutropenia. J Clin Microbiol. 2009;47(8):2405-10.

29. Nakamura A, Sugimoto Y, Ohishi K, Sugawara Y, Fujieda A, Monma F, et al. Diagnostic value of PCR analysis of bacteria and fungi from blood in 
empiric-therapy-resistant febrile neutropenia. J Clin Microbiol. 2010;48(6):2030-6.

30. Lamoth F, Jaton K, Prod'hom G, Senn L, Bille J, Calandra T, et al. Multiplex blood PCR in combination with blood cultures for improvement of microbiological documentation of infection in febrile neutropenia. J Clin Microbiol. 2010;48(10):3510-6.

31. Kellogg JA, Manzella JP, Bankert DA. Frequency of low-level bacteremia in children from birth to fifteen years of age. J Clin Microbiol. 2000;38(6):2181-5.

Submit your next manuscript to BioMed Central and take full advantage of:

- Convenient online submission

- Thorough peer review

- No space constraints or color figure charges

- Immediate publication on acceptance

- Inclusion in PubMed, CAS, Scopus and Google Scholar

- Research which is freely available for redistribution 